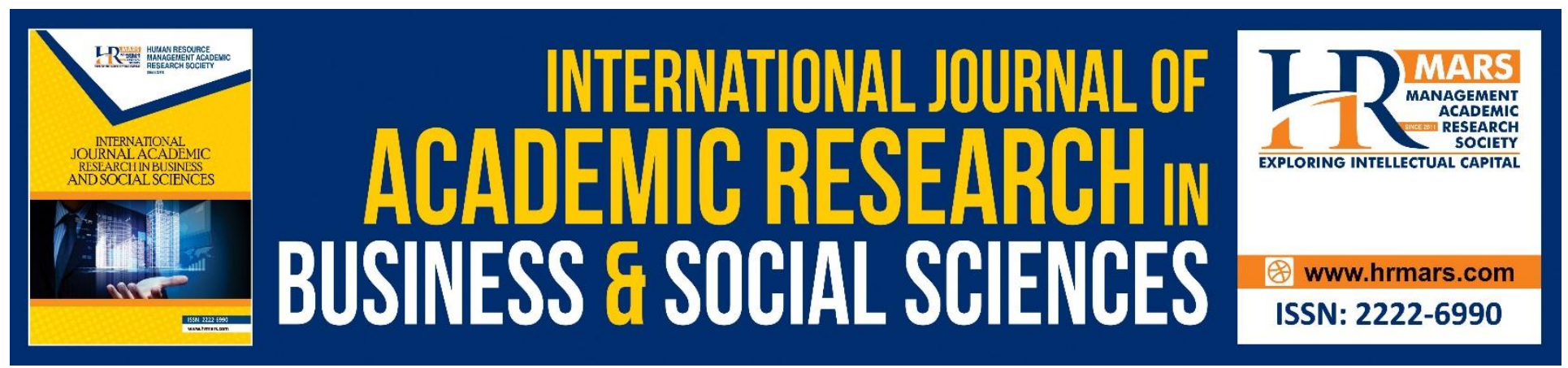

\title{
Peer Feedback in Technology-Supported Learning Environment: A Comprehensive Review
}

Catherine Nguoi Chui Lam, Hadina Bt. Habil

To Link this Article: http://dx.doi.org/10.6007/IJARBSS/v10-i9/7866

DOI:10.6007/IJARBSS/v10-i9/7866

Received: 28 June 2020, Revised: 22 July 2020, Accepted: 18 August 2020

Published Online: 07 September 2020

In-Text Citation: (Lam, \& Habil, 2020)

To Cite this Article: Lam, C. N. C., \& Habil, H. Bt. (2020). Peer Feedback in Technology-Supported Learning Environment: A Comprehensive Review. International Journal of Academic Research in Business and Social Sciences. 10(9), 762-784.

Copyright: (C) 2020 The Author(s)

Published by Human Resource Management Academic Research Society (www.hrmars.com)

This article is published under the Creative Commons Attribution (CC BY 4.0) license. Anyone may reproduce, distribute, translate and create derivative works of this article (for both commercial and non-commercial purposes), subject to full attribution to the original publication and authors. The full terms of this license may be seen

at: http://creativecommons.org/licences/by/4.0/legalcode

\section{Vol. 10, No. 9, 2020, Pg. 762 - 784}

Full Terms \& Conditions of access and use can be found at http://hrmars.com/index.php/pages/detail/publication-ethics 


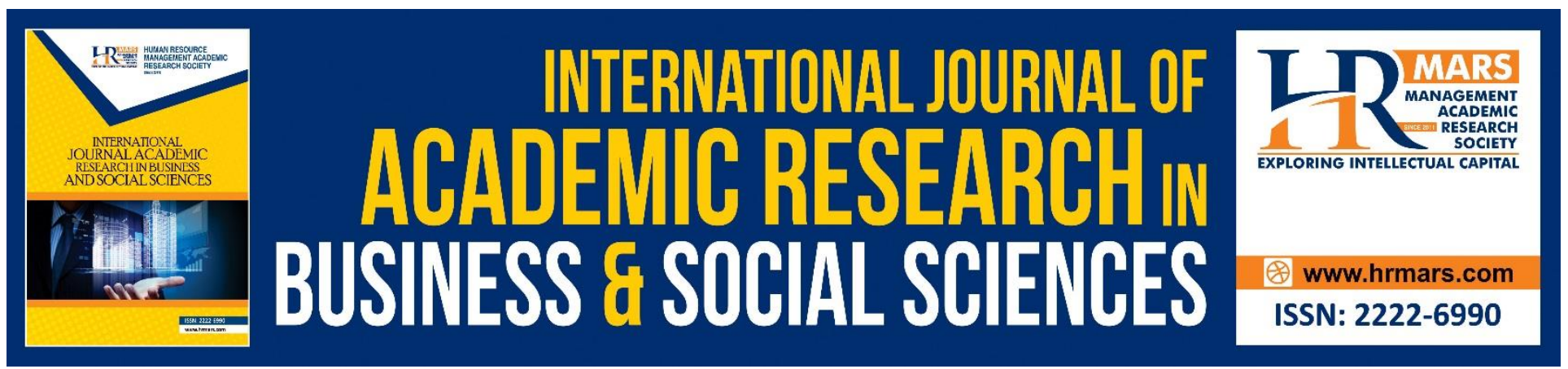

\title{
Peer Feedback in Technology-Supported Learning Environment: A Comprehensive Review
}

\author{
Catherine Nguoi Chui Lam¹, Hadina Bt. Habil ${ }^{2}$ \\ ${ }^{1}$ Faculty of Education, Universiti Teknologi Malaysia, 81310 Skudai, Malaysia, ${ }^{2}$ Language Academy, \\ Universiti Teknologi Malaysia, 81310 Skudai, Malaysia.
}

\begin{abstract}
In this paper, a review of literature was undertaken to explore peer feedback studies in technologysupported learning environment. The objectives are to: (1) find out the extent to which technologysupported peer feedback has been studied in different contexts of teaching and learning (2) identify the opportunities/ affordances offered by technology-supported peer feedback activity and (3) summarize the potential challenges/ constraints of technology-supported peer feedback activity. Articles related to peer feedback practices conducted with the use of technology were searched from two databases: ScienceDirect and Taylor \& Francis Online from 2015 to 2019. Of the final 33 articles selected for full review, 25 studies (75.8\%) were conducted in the context of student writing and the three most productive research lines identified are different types/ characteristics of peer feedback, students' perceptions on their experience of doing peer feedback activity and the impacts of peer feedback on students' learning performance. Five most dominant affordances of technologysupported peer feedback activity were identified as follows: (1) opportunities to get high-quality feedback for student learning (2) promoting students' deep self-reflection (3) convenience and ease (4) creating a safe and supportive learning environment and (5) opportunities to get peer support through interaction. Meanwhile, four main challenges were summarized as: (1) students' lack of confidence to provide feedback (2) the lack of constructive peer feedback (3) students' lack of trust in their peers' ability to provide feedback and (4) students' lack of active response to peer feedback. Some recommendations arising from the review are also discussed in this paper.
\end{abstract}

Keywords: Peer Feedback, Peer Review, Affordances, Constraints, Technology-Supported.

\section{Introduction}

Peer feedback is defined as "a communication process through which learners enter into dialogues related to performance and standards" (Liu and Carless, 2006, p.280). Peer feedback can be an important tool to facilitate student learning due to following arguments. As highlighted by Cho and MacArthur (2010), 'peers share problems, languages and knowledge', and they normally share the same vocabulary with their peers (Topping, 2010), therefore an "immediate, socially appropriate audience" (Clifford, 1981) can be anticipated in a peer feedback practice. Besides, communication of errors might be less intimidating and more acceptable among students. This is because not all 
INTERNATIONAL JOURNAL OF ACADEMIC RESEARCH IN BUSINESS AND SOCIAL SCIENCES Vol. 10, No. 9, 2020, E-ISSN: 2222-6990 @ 2020 HRMARS

students can successfully process teachers' corrective feedback, particularly learners with high language anxiety (Sheen, 2008).

Despite there is an extensive amount of literature on peer feedback, most of the studies were limited to face-to-face learning environment. Recent trends in peer feedback practices, however have evidenced the use of technology. The ubiquitous presence of technology has inspired technologysupported teaching and learning which allows peer feedback to be incorporated seamlessly into the classroom.

Given the growing importance of technology in peer feedback practices, articles related to peer feedback practices conducted with the use of technology were explored and reviewed to provide a background to appropriately position new research as well as to identify any potential research areas for further investigation.

\section{Research Objectives}

The objectives of this paper are outlined as follows: (1) to find out the extent to which technologysupported peer feedback has been studied in different contexts of teaching and learning (2) to identify the opportunities offered by technology-supported peer feedback activity and (3) to summarize the potential challenges/ constraints of technology-supported peer feedback activity.

\section{Methodology}

In order to conduct the literature review, the following steps which were suggested by Xiao and Watson (2017) were used: formulating the research problem, developing the review protocol, searching for literature, screening for inclusion, assessing quality, extracting data, analyzing and synthesizing data and reporting the findings.

In order to narrow down the research topic and formulate research questions which are sufficiently specific, a pre-review mapping was used to identify and choose the subtopics within the predefined scope. Next, a review protocol which specifies how the review will be conducted, was developed. This includes defining search strategies and inclusion criteria. Defining a search strategy involves two main stages (Keele, 2007): (1) identification of key words from research questions and (2) identification of the source of studies such as digital libraries, journals and conferences. As a result, two sets of keywords defined from the research questions: (1) feedback-related keywords, including peer feedback, peer response and peer review and (2) technology-related keywords, including mobile-assisted, online, technology-supported and technology-enhanced were used to generate the search string.

In order to be included in this review, studies have to meet the following criteria: studies published during the period 2015-2019; present empirical data and focus on teaching and learning. Studies were excluded if they were not in the context of student learning, or if the main subject is concerned with teacher feedback, traditional peer feedback practice without the use of any technological tool, peer assessment without qualitative feedback, peer interaction such as collaborative practices or peer editing without involving peer feedback. Publications such as book reviews, review articles, letters, responses, commentaries, and editorial materials were also excluded. Based on the selection criteria, two electronic databases: ScienceDirect and Taylor \& Francis Online were searched from 2015 to 2019, targeting at related research articles in the five most recent years. 
INTERNATIONAL JOURNAL OF ACADEMIC RESEARCH IN BUSINESS AND SOCIAL SCIENCES Vol. 10, No. 9, 2020, E-ISSN: 2222-6990 @ 2020 HRMARS

For initial screening, the research title, abstract and keywords of the articles were used to flag an article as whether it is potentially relevant for a further review. With a thorough examination, a total of 33 research articles identified to have some bearing on the specific research questions formulated for this paper, were selected and reviewed.

Guided by the aforementioned research questions, information which serves as the raw material for synthesis was extracted from each article and organized using a literature matrix. Next, a thematic analysis (Braun \& Clarke, 2006), which involves steps of familiarizing with data, generating initial codes, searching for themes, reviewing themes, defining and naming themes and producing report, was conducted.

\section{Results and Discussion}

The findings are presented in three sections: (1) research focus and classroom context in technology-supported peer feedback studies (2) affordances of technology-supported peer feedback activity and (3) challenges/ constraints of technology-supported peer feedback activity.

\section{Research Focus of Technology-Supported Peer Feedback Studies}

An overview of the research focus of technology-supported peer feedback studies is illustrated in Table 1. Based on Table 1, the three most productive strands of technology-supported peer feedback studies are: the different types/ characteristics of peer feedback (51.5\%), students' perceptions on their experience of doing peer feedback activity (51.5\%) and the impacts of peer feedback on students' learning performance (39.4\%).

Table 1. Research Focus

\begin{tabular}{|c|c|c|c|}
\hline $\begin{array}{l}\text { Research } \\
\text { Focus }\end{array}$ & Context & Studies & $\%$ \\
\hline \multirow[t]{6}{*}{$\begin{array}{l}\text { Impacts of peer } \\
\text { feedback on } \\
\text { students' } \\
\text { learning } \\
\text { performance }\end{array}$} & writing performance & $\begin{array}{l}\text { Cheng, Liang \& Tsai, 2015; } \\
\text { Jurkowski, 2018; Latifi, } \\
\text { Noroozi, Hatami, \& Biemans, } \\
\text { 2019; Noroozi \& Hatami, 2019; } \\
\text { Qing, 2019; Shang, 2019; van } \\
\text { den Bos \& Tan, 2019; Wu, Petit } \\
\text { \& Chen, 2015; Zheng, Cui, Li \& } \\
\text { Huang, } 2017\end{array}$ & \multirow[t]{4}{*}{39.4} \\
\hline & reading scores & Yang (2015) & \\
\hline & $\begin{array}{l}\text { speaking performance } \\
\text { oral proficiency development }\end{array}$ & $\begin{array}{l}\text { Chien, Hwang \& Jong (2019) } \\
\text { Liu (2016) }\end{array}$ & \\
\hline & translation quiz scores & Ge (2019) & \\
\hline & $\begin{array}{l}\text { argumentative feedback } \\
\text { quality of online unscripted, } \\
\text { scripted and guided conditions }\end{array}$ & $\begin{array}{l}\text { Latifi, Noroozi, Hatami, \& } \\
\text { Biemans (2019) }\end{array}$ & \\
\hline & $\begin{array}{l}\text { validity of peer } \\
\text { compared } \\
\text { suggestions }\end{array}$ & Wu, Petit \& Chen (2015) & \\
\hline
\end{tabular}


INTERNATIONAL JOURNAL OF ACADEMIC RESEARCH IN BUSINESS AND SOCIAL SCIENCES Vol. 10, No. 9, 2020, E-ISSN: 2222-6990 @ 2020 HRMARS

\begin{tabular}{|c|c|c|c|}
\hline \multirow[t]{4}{*}{$\begin{array}{l}\text { Quality of peer } \\
\text { feedback }\end{array}$} & $\begin{array}{l}\text { feedback quality produced by } \\
\text { HEP and LEP students }\end{array}$ & Wu (2019) & \multirow[t]{4}{*}{18.2} \\
\hline & $\begin{array}{l}\text { feedback quality index in } \\
\text { different conditions: with a } \\
\text { feedback request, a content } \\
\text { checklist, a combination } \\
\text { condition }\end{array}$ & Gielen \& De Wever (2015) & \\
\hline & $\begin{array}{l}\text { quality of peer feedback in a } \\
\text { repeating blind peer review } \\
\text { cycle }\end{array}$ & Gaynor (2019) & \\
\hline & $\begin{array}{l}\text { quality of peer feedback in } \\
\text { terms of affective, cognitive } \\
\text { and metacognitive feedback }\end{array}$ & Zheng, Cui, Li \& Huang (2017) & \\
\hline \multirow{11}{*}{$\begin{array}{l}\text { Types/ } \\
\text { characteristics } \\
\text { of peer } \\
\text { feedback }\end{array}$} & $\begin{array}{l}\text { patterns of foci of feedback } \\
\text { related to research proposals } \\
\text { preparation }\end{array}$ & Al Qunayeer (2019) & \multirow{11}{*}{51.5} \\
\hline & $\begin{array}{l}\text { suggestions, praise \& wiki } \\
\text { writing criteria }\end{array}$ & Qing (2019) & \\
\hline & $\begin{array}{l}\text { criticism, questions, } \\
\text { suggestions }\end{array}$ & Luo (2016) & \\
\hline & $\begin{array}{l}\text { feedback comment, depth and } \\
\text { tone }\end{array}$ & Walker (2015) & \\
\hline & $\begin{array}{l}\text { evaluative position, aspect of } \\
\text { composition, effect, non- } \\
\text { declarative formulations, } \\
\text { explicit reference to } \\
\text { participants, communicative } \\
\text { response }\end{array}$ & Chwo (2015) & \\
\hline & $\begin{array}{l}\text { directive, nondirective, lower- } \\
\text { order concerns, higher-order } \\
\text { concerns }\end{array}$ & van den Bos \& Tan (2019) & \\
\hline & global and local areas & Li \& Li (2017) & \\
\hline & praise, Criticism, and Opinion & Chien, Hwang \& Jong (2019) & \\
\hline & $\begin{array}{l}\text { audience-aware feedback and } \\
\text { affectivity of reviewer } \\
\text { comments: tone, focus and } \\
\text { stance }\end{array}$ & Chang (2015) & \\
\hline & $\begin{array}{l}\text { comparison of characteristics } \\
\text { of peer feedback of } f 2 f \text { groups } \\
\text { and online groups }\end{array}$ & Pritchard \& Morrow (2017) & \\
\hline & $\begin{array}{lr}\text { corrective } & \text { feedback: explicit } \\
\text { correction, } & \text { metalinguistic }\end{array}$ & Akiyama (2017) & \\
\hline
\end{tabular}


INTERNATIONAL JOURNAL OF ACADEMIC RESEARCH IN BUSINESS AND SOCIAL SCIENCES Vol. 10, No. 9, 2020, E-ISSN: 2222-6990 @ 2020 HRMARS

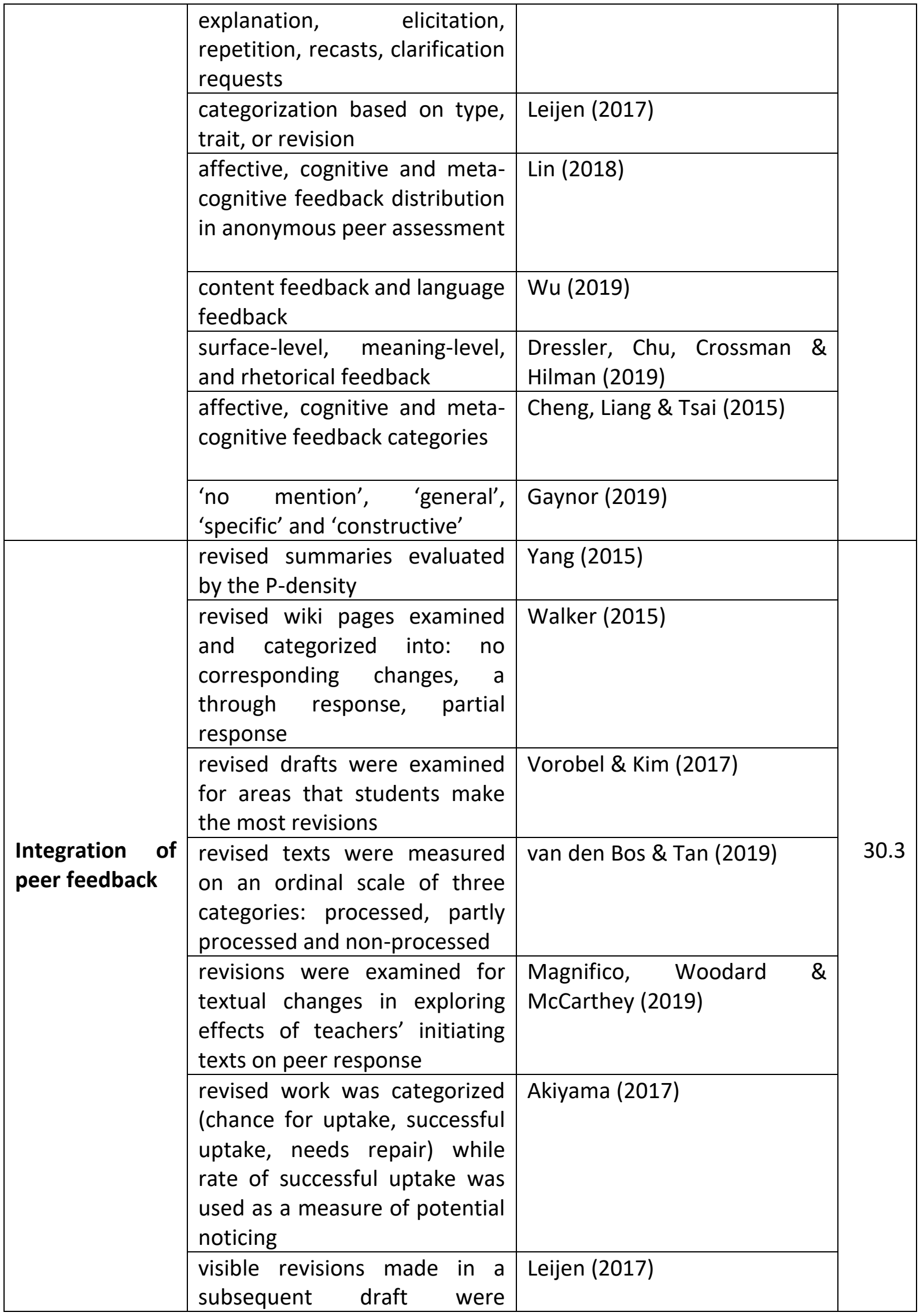


INTERNATIONAL JOURNAL OF ACADEMIC RESEARCH IN BUSINESS AND SOCIAL SCIENCES Vol. 10, No. 9, 2020, E-ISSN: 2222-6990 @ 2020 HRMARS

\begin{tabular}{|c|c|c|c|}
\hline & $\begin{array}{l}\text { examined for feedback } \\
\text { instances to be categorized as } \\
\text { revised or not revised }\end{array}$ & & \\
\hline & $\begin{array}{l}\text { final drafts were examined for } \\
\text { students' integration of peer } \\
\text { feedback }\end{array}$ & Jurkowski (2018) & \\
\hline & $\begin{array}{l}\text { student uptake was examined } \\
\text { for quantity and quality (by } \\
\text { assigning a percentage value to } \\
\text { the uptake) }\end{array}$ & $\begin{array}{l}\text { Dressler, Chu, Crossman \& } \\
\text { Hilman (2019) }\end{array}$ & \\
\hline & $\begin{array}{l}\text { revised thesis drafts were used } \\
\text { to explain participants' learning }\end{array}$ & Yu (2019) & \\
\hline \multirow{11}{*}{$\begin{array}{l}\text { Students' } \\
\text { perceptions on } \\
\text { their } \\
\text { experience of } \\
\text { doing peer } \\
\text { feedback } \\
\text { activity }\end{array}$} & perceived satisfaction & Shang (2019) & \multirow{11}{*}{51.5} \\
\hline & $\begin{array}{l}\text { perceived opportunities/ } \\
\text { usefulness/ learning/ benefits }\end{array}$ & $\begin{array}{l}\text { Al Qunayeer, 2019; Gaynor, } \\
\text { 2019; Latifi, Noroozi, Hatami, } \\
\text { \& Biemans, 2019; Lin, 2018; } \\
\text { Luo, 2016, Qing, 2019; Vorobel } \\
\text { \& Kim, 2017; Yang, 2015; Yu, } \\
2019\end{array}$ & \\
\hline & perceived challenges & $\begin{array}{l}\text { Al Qunayeer, 2019; Hung, } \\
\text { 2016; } \\
\text { Vorobel \& Kim, } 2017\end{array}$ & \\
\hline & $\begin{array}{l}\text { students' appreciation of the } \\
\text { module }\end{array}$ & $\begin{array}{l}\text { Latifi, Noroozi, Hatami, \& } \\
\text { Biemans (2019) }\end{array}$ & \\
\hline & $\begin{array}{l}\text { perceived ease of use of the } \\
\text { module }\end{array}$ & $\begin{array}{l}\text { Latifi, Noroozi, Hatami, \& } \\
\text { Biemans (2019) }\end{array}$ & \\
\hline & $\begin{array}{l}\text { perceived enjoyment and } \\
\text { motivation }\end{array}$ & Grant (2016) & \\
\hline & perceived effort & Grant (2016) & \\
\hline & $\begin{array}{l}\text { perceived difference to regular } \\
\text { class }\end{array}$ & Grant (2016) & \\
\hline & $\begin{array}{l}\text { perceived effects of the } \\
\text { domain-general learning }\end{array}$ & $\begin{array}{l}\text { Latifi, Noroozi, Hatami, \& } \\
\text { Biemans (2019) }\end{array}$ & \\
\hline & $\begin{array}{l}\text { participants' comfort and } \\
\text { preferences in receiving and } \\
\text { giving feedback }\end{array}$ & Pritchard \& Morrow (2017) & \\
\hline & $\begin{array}{l}\text { overall perceptions on task/ } \\
\text { peer review/ instructional } \\
\text { design }\end{array}$ & $\begin{array}{l}\text { Gielen \& De Wever ,2015; Li \& } \\
\text { Li, 2017; Liu, 2016; Wu, Petit \& } \\
\text { Chen, } 2015\end{array}$ & \\
\hline
\end{tabular}


INTERNATIONAL JOURNAL OF ACADEMIC RESEARCH IN BUSINESS AND SOCIAL SCIENCES Vol. 10, No. 9, 2020, E-ISSN: 2222-6990 @ 2020 HRMARS

\begin{tabular}{|c|c|c|c|}
\hline \multirow[b]{2}{*}{$\begin{array}{l}\text { Student beliefs/ } \\
\text { attitudes }\end{array}$} & $\begin{array}{l}\text { relationship between learner } \\
\text { beliefs and successful uptake } \\
\text { students' epistemic beliefs }\end{array}$ & $\begin{array}{l}\text { Akiyama (2017) } \\
\text { Noroozi \& Hatami (2019) }\end{array}$ & \multirow[b]{2}{*}{12.1} \\
\hline & $\begin{array}{l}\text { attitude towards the system } \\
\text { used } \\
\text { attitudes towards peer video } \\
\text { feedback } \\
\text { attitudinal change for various } \\
\text { aspects of the topic used }\end{array}$ & $\begin{array}{l}\text { Lin }(2018) \\
\text { Ge (2019) }\end{array}$ & \\
\hline \multirow[t]{2}{*}{$\begin{array}{l}\text { Consideration } \\
\text { of peer } \\
\text { feedback }\end{array}$} & $\begin{array}{l}\text { effects of question prompt on } \\
\text { learners' consideration of peer } \\
\text { feedback } \\
\text { evaluation of the received } \\
\text { feedback }\end{array}$ & Gielen \& De Wever (2015) & \multirow[t]{2}{*}{9.1} \\
\hline & $\begin{array}{l}\text { perceived fairness of peer } \\
\text { comments }\end{array}$ & $\operatorname{Lin}(2018)$ & \\
\hline $\begin{array}{l}\text { Effects of peer } \\
\text { review training }\end{array}$ & $\begin{array}{l}\text { audience-aware feedback and } \\
\text { affectivity of reviewer } \\
\text { comments before and after } \\
\text { teacher modelling }\end{array}$ & Chang (2015) & 3.0 \\
\hline \multirow[t]{3}{*}{$\begin{array}{l}\text { Leaning } \\
\text { behaviour }\end{array}$} & $\begin{array}{lll}\text { peer review } & \text { process } \\
\text { completion rates } & \\
\end{array}$ & Grant (2016) & \multirow[t]{3}{*}{9.1} \\
\hline & $\begin{array}{l}\text { relation between learners' } \\
\text { English proficiency and peer } \\
\text { feedback performance }\end{array}$ & Wu (2019) & \\
\hline & $\begin{array}{l}\begin{array}{l}\text { students' engagement and } \\
\text { strategies }\end{array} \\
\end{array}$ & Hung (2016) & \\
\hline \multirow[t]{6}{*}{$\begin{array}{l}\text { Other effects of } \\
\text { peer feedback }\end{array}$} & $\begin{array}{ll}\begin{array}{l}\text { students' meta-cognitive } \\
\text { awareness }\end{array} & \\
\end{array}$ & Zheng, Cui, Li \& Huang (2017) & \multirow{6}{*}{9.1} \\
\hline & students' self-efficacy & Zheng, Cui, Li \& Huang (2017) & \\
\hline & students' leaning motivation & Chien, Hwang \& Jong (2019) & \\
\hline & students' critical thinking skills & Chien, Hwang \& Jong (2019) & \\
\hline & English learning anxiety & Chien, Hwang \& Jong (2019) & \\
\hline & willingness to communicate & Liu (2016) & \\
\hline
\end{tabular}

It was evident that many studies (51.5\%) have explored the different types of peer feedback from different aspects. Therefore, different classification schemes of peer feedback, such as suggestions and praise (Qing, 2019), criticism, questions and suggestions (Luo,2016), feedback comment, depth and tone (Walker, 2015), evaluative position, aspect of composition, effect, non-declarative formulations, explicit reference to participants, communicative response (Chwo, 2015), directive, nondirective, lower-order concerns and higher-order concerns (van den Bos \& Tan (2019), global and 
INTERNATIONAL JOURNAL OF ACADEMIC RESEARCH IN BUSINESS AND SOCIAL SCIENCES Vol. 10, No. 9, 2020, E-ISSN: 2222-6990 @ 2020 HRMARS

local areas (Li \& Li, 2017), praise, criticism, and opinion (Chien, Hwang \& Jong (2019), audience-aware feedback and affectivity of reviewer comments: tone, focus and stance (Chang, 2015), explicit correction, metalinguistic explanation, elicitation, repetition, recasts, clarification requests of corrective feedback (Akiyama, 2017), categorization based on type, trait and revision (Leijen, 2017), affective, cognitive and meta-cognitive feedback (Cheng, Liang \& Tsai, 2015; Lin, 2018), suggestion, clarification request, problem description, praise for content feedback and suggestion, clarification request, problem description, metalinguistic explanation, direct correction, praise for language feedback (Wu, 2019), surface-level, meaning-level, and rhetorical feedback (Dressler, Chu, Crossman \& Hilman, 2019), 'general', 'specific' and 'constructive' feedback (Gaynor, 2019) were found in the literature.

Another popular line of research is concerned with students' perceptions on their experience of doing peer feedback activity (51.5\%). Among these, students' perceived satisfaction (Shang, 2019), perceived opportunities/ usefulness/ learning/ benefits with regards to peer feedback activity (Al Qunayeer, 2019; Gaynor, 2019; Latifi, Noroozi, Hatami, \& Biemans, 2019; Lin, 2018; Luo, 2016, Qing, 2019; Vorobel \& Kim, 2017; Yang, 2015; Yu, 2019), perceived challenges with regards to peer feedback activity (Al Qunayeer, 2019; Hung, 2016; Vorobel \& Kim, 2017), students' appreciation of the module and ease of use of the module mediated by peer feedback (Latifi, Noroozi, Hatami, \& Biemans, 2019), perceived enjoyment and motivation, effort and difference to regular class Grant (2016), perceived effects of the domain-general learning (Latifi, Noroozi, Hatami, \& Biemans, 2019) their comfort and preferences in receiving and giving feedback (Pritchard \& Morrow, 2017) and their overall perceptions on the task/ peer review/ instructional design (Gielen \& De Wever ,2015; Li \& Li, 2017; Liu, 2016; Wu, Petit \& Chen, 2015) were explored.

Studies that explored the impacts of peer feedback on learning performance (39.4\%) centred around students' writing performance (Cheng, Liang \& Tsai, 2015; Jurkowski, 2018; Latifi, Noroozi, Hatami, \& Biemans, 2019; Noroozi \& Hatami, 2019; Qing, 2019; Shang, 2019; van den Bos \& Tan, 2019; Wu, Petit \& Chen, 2015; Zheng, Cui, Li \& Huang, 2017) and speaking performance (Chien, Hwang \& Jong, 2019; Liu, 2016).

Some studies (30.3\%) also examined students' integration of peer feedback in their revised work (Akiyama, 2017; Dressler, Chu, Crossman \& Hilman, 2019; Jurkowski, 2018, Leijen, 2017; Magnifico, Woodard \& McCarthey, 2019; van den Bos \& Tan , 2019; Vorobel \& Kim, 2017; Walker, 2015; Yang, 2015; Yu, 2019).

Other lines of research involved exploration into the quality of peer feedback (18.2\%), student beliefs or attitudes (12.1\%), consideration of peer feedback (9.1\%), learning behaviour (9.1\%), other effects of peer feedback (9.1\%) on students' meta-cognitive awareness, self-efficacy, leaning motivation, critical thinking skills, English learning anxiety, willingness to communicate and effects of peer review training (3.0\%).

The aforementioned findings revealed that an overwhelming attention was addressed to different types/ characteristics of feedback, students' perceptions on peer feedback experience and impacts of peer feedback on learning performance. There is relatively little research that delves into students' integration of peer feedback in their revised work. As echoed in Walker's (2015) paper, research on peer feedback should put the focus on students using feedback rather than giving feedback. As student revision is an important part of a peer review activity, exploration into students' integration 
INTERNATIONAL JOURNAL OF ACADEMIC RESEARCH IN BUSINESS AND SOCIAL SCIENCES Vol. 10, No. 9, 2020, E-ISSN: 2222-6990 @ 2020 HRMARS

of peer feedback on their subsequent work will definately shed some valuable insights on the efficacy of peer feedback.

\section{Classroom Context in Technology-Supported Peer Feedback Studies}

Table 2 summarizes the classroom context of technology-supported peer feedback studies. Of all the 33 peer feedback studies included in the final synthesis, 25 studies (75.8\%) were conducted in the context of student writing, which include essays of different format such as 120-word (Zheng, Cui, Li \& Huang, 2017), 500-word (Chang, 2015) and 4-paragraph essay (Shang, 2019) and different genres, such as argumentative essay (Latifi, Noroozi, Hatami \& Biemans, 2019; Leijen, 2017; Li \& Li, 2017; Noroozi \& Hatami, 2019; van den Bos \& Tan, 2019), narrative writing (Wu, 2019), imaginative story (Chwo, 2015), personal expressive writing (Pritchard \& Morrow, 2017), descriptive essay Vorobel \& Kim (2017), persuasive essay (Magnifico, Woodard \& McCarthey, 2019), reaction paper (Li \& Li, 2017; Wu, Petit \& Chen, 2015), problem-solution essay (Grant, 2016), report writing (Cheng, Liang, \& Tsai, 2015; Dressler, Chu, Crossman, \& Hilman, 2019; Walker, 2015), summary writing (Li \& Li, 2017; Yang (2015), abstract writing (Gielen \& De Wever, 2015), research proposal writing (Al Qunayeer, 2019), thesis/ dissertation (Yu, 2019), term paper (Jurkowski, 2018 ), a book chapter (Qing, 2019), reflective reviews and other assignments (Gaynor, 2019).

Table 2. Classroom Context

\begin{tabular}{|c|c|c|}
\hline $\begin{array}{c}\text { Classroom } \\
\text { Context }\end{array}$ & Approach & Studies \\
\hline $\begin{array}{l}\text { Student } \\
\text { writing }\end{array}$ & 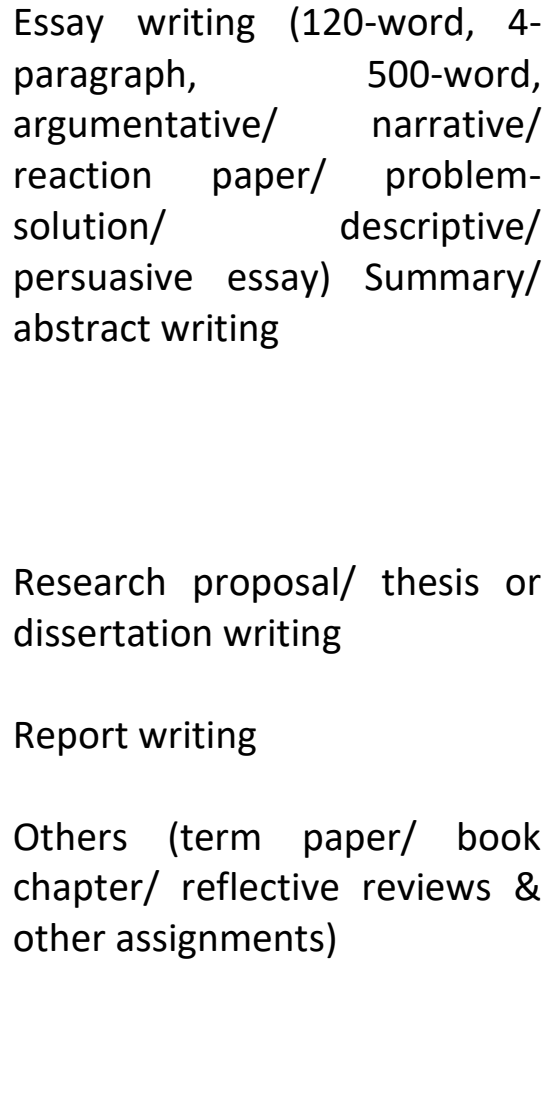 & $\begin{array}{l}\text { Chang, 2016; Chwo, 2015; Grant, 2016; } \\
\text { Latifi, Noroozi, Hatami \& Biemans, 2019; } \\
\text { Leijen, 2017; Li \& Li, 2017; Magnifico, } \\
\text { Woodard \& McCarthey, 2019; Noroozi } \\
\text { \& Hatami, 2019; Shang, 2019; Pritchard } \\
\text { \& Morrow, 2017; van den Bos \& Tan, } \\
\text { 2019; Vorobel \& Kim, 2017; Wu, 2019; } \\
\text { Wu, Petit \& Chen, 2015; Zheng, Cui, Li \& } \\
\text { Huang, 2017 } \\
\text { Gielen \& De Wever, 2015; Li \& Li, 2017; } \\
\text { Yang, 2015 } \\
\text { Al Qunayeer, 2019; Yu, 2019 } \\
\text { Cheng, Liang, \& Tsai, 2015; Dressler, } \\
\text { Chu, Crossman, \& Hilman, 2019; Walker, } \\
2015\end{array}$ \\
\hline
\end{tabular}


INTERNATIONAL JOURNAL OF ACADEMIC RESEARCH IN BUSINESS AND SOCIAL SCIENCES Vol. 10, No. 9, 2020, E-ISSN: 2222-6990 @ 2020 HRMARS

\begin{tabular}{|c|l|l|}
\hline $\begin{array}{l}\text { Student } \\
\text { speaking }\end{array}$ & $\begin{array}{l}\text { Oral presentation / speech } \\
\text { Learning films produced by } \\
\text { talking } \\
\text { to virtual characters } \\
\text { Audio record of conversation }\end{array}$ & $\begin{array}{l}\text { Hung, 2016; Liu, 2016; Luo, 2016; } \\
\text { Chien, Hwang \& Jong (2019) } \\
\text { Akiyama (2017) }\end{array}$ \\
\hline Others & $\begin{array}{l}\text { Translation quizzes } \\
\text { Vocabulary task }\end{array}$ & $\begin{array}{l}\text { Ge (2019) } \\
\text { Montero-Fleta, Pérez-Sabater \& Pérez- } \\
\text { Sabater (2015) } \\
\text { Lin (2018) }\end{array}$ \\
\hline
\end{tabular}

Only a small number of studies (15.2\%) conducted peer feedback studies in the context of student speaking. Among all the studies conducted in speaking context, $60 \%$ of them focused on developing students' oral presentation or speech delivery skills, which involve group project presentation (Luo, 2016), video-taped speech files (Liu, 2016) and speech videos (Hung, 2016). The other two studies (Akiyama, 2017; Chien, Hwang \& Jong, 2019) are more concerned with developing students' oral communication skills.

Apart from writing and speaking contexts, other studies also involved the use of peer feedback in translation quizzes (Ge, 2019), vocabulary task (Montero-Fleta, Pérez-Sabater \& Pérez-Sabater, 2015) and micro-teaching (Lin, 2018).

\section{Affordances of technology-supported peer feedback activity}

Empirically, previous studies have demonstrated that peer feedback can improve students' writing performance (Zheng, Cui, Li \& Huang, 2017). Students were found to produce higher quality of argumentative essays in posttest compared to their pretest (Noroozi \& Hatami, 2019). Students were also reported to improve their sentence writing, make fewer grammatical errors, and produce more types of lexical items (Shang, 2019). Similarly, peer feedback activity designed in the scripted (Latifi, Noroozi, Hatami \& Biemans, 2019) and anonymous condition (van den Bos \& Tan, 2019) were found to contribute to students' better writing performance. In the context of speaking, students in the SVVR environment with PA approach were found to perform better in terms of fluency, comprehension and maturity of the language (Chien, Hwang \& Jong, 2019). In the same way, students' reading comprehension and academic writing skills were found to improve through a peer feedback mediated learning activity. Students have benefitted in terms of recognizing the key elements in well-organized academic texts, clarifying illogical sentences and text misunderstanding with the summary revisions from their peers (Yang, 2015).

These findings concur with a bulk of evidence gathered from students' positive perceptions on the peer feedback activity. Students reported that they have improved writing skills and achievement (Zheng, Cui, Li \& Huang, 2017) and enhanced awareness of the academic thesis genre after composing peer feedback (Yu, 2019). Other studies reported that peer feedback helped students to write a wellstructured and sound argumentative essay (Latifi, Noroozi, Hatami \& Biemans, 2019), refine research proposals and learn better about the process of research proposal development (Al Qunayeer, 2019), improve content, organization and layout of their wiki chapter (Qing, 2019), progress in the organization for composing an essay (Wu, Petit \& Chen, 2015) and improve their grammatical accuracy and vocabulary use, ideas development as well as revision and citation (Li \& Li, 2017). 76\% 
INTERNATIONAL JOURNAL OF ACADEMIC RESEARCH IN BUSINESS AND SOCIAL SCIENCES Vol. 10, No. 9, 2020, E-ISSN: 2222-6990 @ 2020 HRMARS

of participants reported that online peer feedback helped them to resolve many summary writing difficulties, thus reducing their writing anxiety (Yang, 2015). Table 3 gives a summary of the affordances of technology-supported peer feedback activity identified from the studies reviewed.

Table 3. Affordances of technology-supported peer feedback activity

\begin{tabular}{|c|c|}
\hline Affordances & Studies \\
\hline Promoting Deep Self-Reflection & $\begin{array}{l}\text { Al-Qunayeer, 2019; Chien, Hwang \& Jong, } \\
\text { 2019; Dressler, Chu, Crossman, \& Hilman, } \\
\text { 2019; Li \& Li, 2017; Vorobel \& Kim, 2017, } \\
\text { Wu, Petit and Chen, 2015; Yang, 2015; Yu, } \\
\text { 2019; Zheng, Cui, Li \& Huang, } 2017\end{array}$ \\
\hline Opportunities to Get High-quality Feedback & $\begin{array}{l}\text { Al Qunayeer, 2019; Chang, 2015; Gaynor, } \\
\text { 2019; Gielen \& De Wever, 2015; Latifi, } \\
\text { Noroozi, Hatami \& Biemans, 2019; Li \& Li, } \\
\text { 2017; Lin, 2018; Luo, 2016; van den Bos \& } \\
\text { Tan, 2019; Walker, 2015; Wu, 2019; Wu, } \\
\text { Petit \& Chen, 2015; Zheng, Cui, Li \& Huang, } \\
2017\end{array}$ \\
\hline $\begin{array}{l}\text { Creating a Safe and Supportive Learning } \\
\text { Environment }\end{array}$ & $\begin{array}{l}\text { Chien, Hwang \& Jong, 2019; Li \& Li, 2017; } \\
\text { Liu, 2016; Pritchard \& Morrow, 2017; Qing, } \\
\text { 2019; Yang, } 2015\end{array}$ \\
\hline $\begin{array}{l}\text { Opportunities to Get Peer Support Through } \\
\text { Interaction }\end{array}$ & $\begin{array}{l}\text { Al Qunayeer, 2019; Ge, 2019; Li \& Li, 2017; } \\
\text { Luo, 2016; Qing, 2019; Yang, } 2015\end{array}$ \\
\hline Convenience and Ease & $\begin{array}{l}\text { Al Qunayeer, 2019; Ge, 2019; Grant, 2016; Li } \\
\text { \& Li, 2017; Liu, 2016; Shang, 2019; Yang, } \\
2015\end{array}$ \\
\hline $\begin{array}{l}\text { Opportunities to Obtain New Ideas and } \\
\text { Perspectives }\end{array}$ & $\begin{array}{l}\text { Liu, 2016; Noroozi \& Hatami, 2019; Shang, } \\
\text { 2019; Yang, } 2015\end{array}$ \\
\hline $\begin{array}{l}\text { Opportunities to Get Peer Support on } \\
\text { Language-related Issues }\end{array}$ & $\begin{array}{l}\text { Akiyama, 2017; Li \& Li, 2017; Montero-Fleta, } \\
\text { Pérez-Sabater \& Pérez-Sabater, 2015; Qing, } \\
\text { 2019; Yu, } 2019\end{array}$ \\
\hline Opportunities for Repeated Practices & Chien, Hwang \& Jong, 2019; Liu, 2016 \\
\hline $\begin{array}{l}\text { Opportunities to Learn from a Variety of } \\
\text { Sources }\end{array}$ & Ge, 2019; Wu, 2019; Yu, 2019 \\
\hline $\begin{array}{l}\text { Timeliness and Immediacy of Peer } \\
\text { Feedback }\end{array}$ & Liu, 2016; Luo, 2016; Yang, 2015 \\
\hline
\end{tabular}

The five most dominant affordances of technology-supported peer feedback activity were summarized as follows: opportunities to get high-quality feedback for student learning (39.4\%), promoting students' deep self-reflection (27.3\%), convenience and ease (21.2\%), creating a safe and supportive learning environment (18.2\%) and opportunities to get peer support through interaction (18.2\%). 
INTERNATIONAL JOURNAL OF ACADEMIC RESEARCH IN BUSINESS AND SOCIAL SCIENCES Vol. 10, No. 9, 2020, E-ISSN: 2222-6990 @ 2020 HRMARS

\section{Opportunities to Get High-quality Feedback}

While much debate exists regarding the quality of student-generated feedback in comparison with teacher feedback, a substantial body of evidence shows that written comments which are more detailed and constructive (Al Qunayeer, 2019; Li \& Li, 2017) and feedback which was prompt, specific and contextualised (Luo, 2016) were reported in an online environment. In Walker's (2015) study, students were found to produce slightly more comments of depth explain than their tutors. $97 \%$ of comments were usable feedback which addresses genuine shortcoming. Wu, Petit and Chen (2015) reported that while more proficient students have offered $90.8 \%$ correct suggestions for revision, calculated out of the total on-target suggestions, less proficient students were also found to offer $84.9 \%$ correct suggestions for revision. It was also reported that Turnitin peer comments were predominantly revision-oriented feedback (Li \& Li, 2017). This is echoed in Gaynor's (2019) study in which $50-60 \%$ constructive or specific peer feedback was recorded and students' ability to produce good feedback on the more generic criteria, such as structure and English was further highlighted. In both the anonymous and identifiable conditions, learners were found to produce more cognitive and metacognitive peer feedback than affective type (Lin, 2018). In the same vein, other studies reported the significant role of scripted condition (Latifi, Noroozi, Hatami \& Biemans, 2019), anonymity (van den Bos \& Tan, 2019), teacher modelling (Chang, 2015) and peer feedback request (Gielen \& De Wever, 2015) in helping students to produce high quality peer feedback.

Besides, previous studies also demonstrate that students generally hold a positive perception on the quality of peer feedback received. Students highlighted that more accurate and elaborated feedback can be provided for their peers, in terms of content, vocabulary and structure with synchronous discussion in peer feedback activity (Zheng, Cui, Li \& Huang, 2017). The opportunity to exchange more detailed or longer written comments compared to traditional face-to-face session was also addressed in Al Qunayeer's (2019) study. In another study (Li \& Li, 2017), students commented that Turnitin peer review activity enabled them to provide more constructive peer feedback in comparison with face-to-face peer feedback. Furthermore, it was also perceived that low English proficiency learners were able to make effective content feedback, just like high English proficiency learners (Wu, 2019).

\section{Promoting Deep Self-Reflection}

Students reported that engaging in technology-enhanced peer feedback sessions can help promote their deep reflection on writing processes (Zheng, Cui, Li \& Huang, 2017). They can critically analyze their own work (Li \& Li, 2017). This is further echoed in Wu, Petit and Chen's (2015) study when students reported that peer feedback activity has helped them to improve their critical thinking ability when reading an article. Students also reported that they can reflect on themselves to improve their own performance (Chien, Hwang \& Jong, 2019). Students' increased awareness of linguistic errors after identifying linguistic errors in their peer's work was also reported (Yu, 2019).

Students' uptake of peer feedback is closely related to their ability to self-reflect on their own work. It was reported that there were no significant differences in the quantity and quality of uptake between instructor and peer feedback (Dressler, Chu, Crossman, \& Hilman, 2019). This is supported by another study which reported that students who received online peer feedback have shown great improvement in substitution, reordering and consolidation revisions (Yang, 2015). Furthermore, it 
INTERNATIONAL JOURNAL OF ACADEMIC RESEARCH IN BUSINESS AND SOCIAL SCIENCES Vol. 10, No. 9, 2020, E-ISSN: 2222-6990 @ 2020 HRMARS

was also found that $84.4 \%$ of feedback provided on grammar and formatting were addressed in revision (Vorobel \& Kim, 2017). These findings can be explained further with points highlighted by students in other studies, such as students' enhanced understanding of peer feedback (Zheng, Cui, Li \& Huang, 2017) and availability of ample time to clarify misunderstanding (Al-Qunayeer, 2019) in online peer feedback activity. Therefore, they might help to explain why technology-supported peer feedback can contribute to students' effective reflection of their own work.

\section{Convenience and Ease}

Peer feedback activity in online mode was described as convenient and flexible (Grant, 2016; Liu, 2016). Students highlighted that it was easy for them to keep track of their speech performance and give their feedback as it is without time limit and physical barriers (Liu, 2016). Similarly, convenience was also one of the advantages reported by students with regards to the use of Turnitin-based peer review (Li \& Li, 2017). With the use of technological tools, students reported that they could easily download and revise their peers' work online anywhere and anytime (Shang, 2019). Similarly, students also reported that videos could be used anytime and anywhere with mobile phones (Ge, 2019). Positive perceptions on easy-to-use characteristic of the video feedback was also noted as students highlighted that producing video feedback can save more time and energy compared to writing feedback (Ge, 2019). Moreover, an online environment which goes beyond the limitations of time and space allows students to check feedback regularly (Yang, 2015) and take more time to respond to peer comments (Al Qunayeer, 2019; Li \& Li, 2017), elaborate ideas and clarify misunderstanding (Al Qunayeer, 2019). Besides, students commented that they can think thoroughly and organize their feedback many times in Turnitin peer review (Li \& Li, 2017).

\section{Creating a Safe and Supportive Learning Environment}

Online peer feedback was claimed by students to diminish their pressure to give face threatening criticism (Li \& Li, 2017) and was therefore described as 'less intimidating' (Pritchard \& Morrow, 2017). It was reported that certain drawbacks of face-to-face sharing can be overcome in the online environment in that there is no need for feedback receivers to make a spontaneous record of the peer suggestions. As for feedback providers, they are not expected to generate a response on the spot and before their peers, after only one reading. Engaging in a face-to-face peer feedback is more threatening as students are afraid of "losing face" or being embarrassed during face-to-face discussions (Yang, 2015). Furthermore, $80.9 \%$ of participants reported that online speech practice for the peer review activity helped them to reduce their anxiety to present speech in front of real audience (Liu, 2016). Their reflection entries further unveiled that they were less anxious when talking to a machine rather than to their classmates. The same was reported by Chien, Hwang and Jong (2019) when students considered SVVR as a "safe" learning environment and that with the peer assessment approach which includes peer review, it can significantly reduce their English learning anxiety. Students reported that the fear to speak English in SVVR environment was diminished. Furthermore, the ability of an online environment to create a friendly and supportive environment was again confirmed when students were found to provide more positive comments during peer review and the peer feedback activity was perceived to be able to encourage and motivate them to perform better (Qing, 2019). 
INTERNATIONAL JOURNAL OF ACADEMIC RESEARCH IN BUSINESS AND SOCIAL SCIENCES Vol. 10, No. 9, 2020, E-ISSN: 2222-6990 @ 2020 HRMARS

\section{Opportunities to Get Peer Support Through Interaction}

Online peer feedback was reported to spur dialogue around learning (Luo, 2016) and thus was viewed as promoting important social skills for students to interact with peers online (Yang, 2015). Students perceived it as offering great opportunities for them to communicate ideas (Al Qunayeer, 2019), express their own understanding (Luo, 2016), discuss language points (Li \& Li, 2017), raise audience awareness (Qing, 2019) and foster a sense of belonging (Ge, 2019). As highlighted by students in Luo's (2016) study, the interactivity of the classroom with both the content and peers was enhanced via the peer feedback activity.

\section{Opportunities to Obtain New Ideas and Perspectives}

Another affordance offered by online tools and platform is the visibility of all student work. Hence, it is not surprising when students reported that they can get more ideas from their peers (Shang, 2019), learn new writing perspectives (Noroozi \& Hatami, 2019) and view their peers' ideas and thoughts on writing summaries for comparison to be made (Yang, 2015). This is particularly relevant when it was revealed that watching others' feedback clips was a common strategy used by the students (Liu, 2016). The opportunities made available for students to read their peer's essays allowed them to view an issue from different perspectives, such as to discover its pros and cons and this will benefit them to revise and modify their own initial standpoints on the topic discussed (Noroozi \& Hatami, 2019).

\section{Opportunities to Get Peer Support on Language-related Issues}

Peer feedback was found to promote students' noticing of errors in target form when an instruction on corrective feedback was given (Montero-Fleta, Pérez-Sabater \& Pérez-Sabater, 2015). This is further supported by another study which found a positive relationship between learner beliefs and potential noticing of corrective feedback, especially of recast during a peer review (Akiyama, 2017). From the students' perspective, it was reported that online peer feedback can help them to proofread and detect mistakes or flaw (Qing, 2019), address language-related issues (Li \& Li, 2017), improve their grammatical accuracy (Li \& Li, 2017; Shang, 2019) and contribute to their increased linguistic knowledge of academic genres (Yu, 2019).

\section{Opportunities to Learn from a Variety of Sources}

Student learning was promoted when they were engaged in providing feedback on their peers' theses/dissertations as they sought external assistance from a peer or scholarly resources (Yu, 2019). Similarly, online reference materials were used by low English proficiency learners to enhance the quality of their language feedback (Wu, 2019). Peer feedback activity also allowed students to make productive comparison of work. Students reported that comparing answers from different sources during peer review has resulted in their enhanced understanding of translation quiz questions and improvement in the posttest (Ge, 2019).

\section{Timeliness and Immediacy of Peer Feedback}

Students reported that peer feedback can be given without time limit and physical barrier (Liu, 2016). Similarly, timeliness and immediacy of peer feedback were some features noted by students (Luo, 2016). Compared to face-to-face peer feedback, online mode was said to prompt 
INTERNATIONAL JOURNAL OF ACADEMIC RESEARCH IN BUSINESS AND SOCIAL SCIENCES Vol. 10, No. 9, 2020, E-ISSN: 2222-6990 @ 2020 HRMARS

immediate comments (Yang, 2015). As students recalled, any immediate comments can be typed and shared whenever something was noted during the twitter-mediated peer feedback session.

\section{Opportunities for Repeated Practices}

Another affordance of peer feedback activity lies in opportunities provided for students to have repeated practice (Chien, Hwang \& Jong, 2019). As addressed in another study, a more flexible time schedule was made available to practise speech presentations or revise speech content (Liu, 2016). Modifying language and rehearsing what to say were the two most frequently used strategies when students were asked to give oral peer feedback via video.

\section{Potential challenges/ constraints of technology-supported peer feedback activity}

Despite numerous benefits of using technology-supported peer feedback were documented in the literature, some challenges/ constraints derived from technology-supported peer feedback activity are still evident, as summarized in Table 4.

Table 4. Challenges/ constraints of Technology-supported Peer Feedback Activity

\begin{tabular}{|l|l|}
\hline \multicolumn{1}{|c|}{ Constraints/ Challenges } & \multicolumn{1}{|c|}{ Studies } \\
\hline $\begin{array}{l}\text { Students' Lack of Confidence to } \\
\text { Provide Feedback }\end{array}$ & $\begin{array}{l}\text { Al Qunayeer, 2019; Chien, Hwang \& Jong, 2019; } \\
\text { Grant, 2016; Liu, 2016; Montero-Fleta, Pérez-Sabater } \\
\text { \& Pérez-Sabater, 2015; Shang, 2019; Wu, 2019; Wu, } \\
\text { Petit \& Chen, 2015; Yang, 2015; Yu, 2019 }\end{array}$ \\
\hline $\begin{array}{l}\text { Students' Lack of Trust in Their } \\
\text { Peers' Ability to Provide Feedback }\end{array}$ & $\begin{array}{l}\text { Al Qunayeer, 2019; Chien, Hwang \& Jong, 2019; Ge, } \\
\text { 2019; Li \& Li, 2017; Shang, 2019; Vorobel \& Kim, } \\
\text { 2017; Wu, Petit \& Chen, 2015; Yang, 2015 }\end{array}$ \\
\hline Lack of Constructive Peer Feedback & $\begin{array}{l}\text { Akiyama, 2017; Dressler, Chu, Crossman, \& Hilman, } \\
\text { 2019; Gaynor, 2019; Luo, 2016; Magnifico, Woodard } \\
\text { \& McCarthey, 2019; Montero-Fleta, Pérez-Sabater \& } \\
\text { Pérez-Sabater, 2015, Qing, 2019; Wu, 2019; Wu, } \\
\text { Petit \& Chen, 2015 }\end{array}$ \\
\hline $\begin{array}{l}\text { Lack of Active Response to Peer } \\
\text { Feedback }\end{array}$ & $\begin{array}{l}\text { Al Qunayeer, 2019; Dressler, Chu, Crossman, \& } \\
\text { Hilman, 2019; Ge, 2019; Jurkowski, 2018; Leijen, } \\
2017 ; \text { Magnifico, Woodard \& McCarthey, 2019; } \\
\text { Vorobel and Kim, 2017; Walker, 2015 }\end{array}$ \\
\hline $\begin{array}{l}\text { Technical Issues Related to The } \\
\text { Tools Used }\end{array}$ & $\begin{array}{l}\text { Chien, Hwang \& Jong, 2019; Li \& Li, 2017; Liu, 2016; } \\
\text { Luo, 2016 }\end{array}$ \\
\hline $\begin{array}{l}\text { Lack of Proper Etiquette When } \\
\text { Communicating }\end{array}$ & \begin{tabular}{l} 
Li \& Li, 2017; Luo, 2016 \\
\hline Task-related Issues
\end{tabular} \\
\hline Delayed feedback & Chien, Hwang \& Jong, 2019; Grant, 2016; Liu, 2016 \\
\hline Lack of non-verbal cues & \begin{tabular}{l} 
Pritchard \& Morrow, 2017 \\
\hline
\end{tabular} \\
\hline
\end{tabular}

The four main challenges of technology-supported peer feedback activity were summarized as follows: students' lack of confidence to provide feedback (30.3\%), lack of constructive peer feedback 
INTERNATIONAL JOURNAL OF ACADEMIC RESEARCH IN BUSINESS AND SOCIAL SCIENCES Vol. 10, No. 9, 2020, E-ISSN: 2222-6990 @ 2020 HRMARS

(27.3\%), students' lack of trust in their peers' ability to provide feedback (24.2\%) and students' lack of active response to peer feedback (24.2\%).

\section{Students' Lack of Confidence to Provide Feedback}

It was noticed that peer feedback often consists of vague suggestions due to students' lack of confidence in their ability to provide feedback (Wu, Petit \& Chen, 2015). Similarly, students perceived that they lack of self-confidence in evaluating and judging their peers' research proposals (Al Qunayeer, 2019). On the same note, upper-intermediate students perceived that online peer review was difficult for them (Grant, 2016) and it was difficult to identify others' mistakes (Chien, Hwang \& Jong, 2019) and some of them reported that they hesitated to revise their peers' summaries (Yang, 2015). Compared to expert comments, students feel that their comments were not good enough (Wu, Petit \& Chen, 2015), some even doubted their ability to provide meaningful feedback for their peers (Yu, 2019) and some were obviously not confident as they have limited English knowledge (Shang, 2019). Wu (2019) also found that less proficient students made fewer direct changes in language feedback because of their limited English proficiency. Some students commented that they "don't know what to say" and "afraid of losing face if they did not do a good job" (Liu, 2016). The same issue was highlighted by Montero-Fleta, Pérez-Sabater and Pérez-Sabater (2015) when it was found that less proficient students only resorted to mere agreeing due to their lack of confidence when pairing up with more proficient peers.

Though students' lack of confidence in their own ability to provide feedback is one of the main issues highlighted, previous studies have reported many different ways to enhance students' confidence in this context. For instance, with the use of peer feedback request (Gielen \& De Wever, 2015), students believe they would provide more specific feedback, comprising more suggestions on how to improve future work and content checklist was perceived to help the assessor to increase the quality of the peer feedback (Gielen \& De Wever, 2015).

\section{Lack of Constructive Peer Feedback}

The issue on credibility and quality of peer feedback has sparked off considerable debate for decades. For instance, it was found that positive comments provided by students did not necessarily reflect the quality of the peer's work (Qing, 2019). Students' concern about hurting their friends (Akiyama, 2017; Vorobel \& Kim, 2017) can be used to explain this. Only 32.2\% of all feedback tweets in a microblogging-based peer feedback activity with little intervention from instructor were constructive peer feedback and most of the suggestion tweets were focused on addressing the technical issues (Luo, 2016). Besides, peer feedback was found to use primarily general and informing language, consisting of "cheerleading" comments or problem identification without specific suggestions for improvement (Magnifico, Woodard \& McCarthey, 2019). Some students did not even provide feedback but merely commented on their peer's texts (Montero-Fleta, Pérez-Sabater \& Pérez-Sabater, 2015). While it was found that low proficiency learners might not be able to detect mistakes due to their insufficient linguistic knowledge of the target form (Montero-Fleta, PérezSabater \& Pérez-Sabater, 2015), high proficiency learners were also found not to correct obvious mistakes as they reported that they believed their peers were able to rectify obvious issues ( $\mathrm{Wu}$, 2019). Similarly, it was found that many errors were not corrected by native-speaking partners (Akiyama, 2017). Compared to instructor, students were found to provide more surface-level feedback (Dressler, Chu, Crossman, \& Hilman, 2019). This is further supported by another study which 
INTERNATIONAL JOURNAL OF ACADEMIC RESEARCH IN BUSINESS AND SOCIAL SCIENCES Vol. 10, No. 9, 2020, E-ISSN: 2222-6990 @ 2020 HRMARS

found that students were inclined to address issues which were within their ability level (Wu, Petit \& Chen, 2015). On the other hand, Qing (2019) justified that the considerably lower number of critical language comments found in her study was most probably due to the 'face threatening' factor in which the high level of visibility of message in wiki open learning environment might have prevented students from directly correcting the language errors made by their peers. As providing feedback involves high-level cognitive processing (King, 2002), efforts should be put on training students on how to provide more specific comments. As suggested by Qing (2019), for language courses which aim to improve the language skills, students can be encouraged to look for language problems/issues so as to reinforce their second language learning.

\section{Students' Lack of Trust in Their Peers' Ability to Provide Feedback}

Some postgraduates cast their doubts on reliability of the ideas and suggestions given by their peers (Al Qunayeer, 2019). Similarly, teacher feedback was viewed as more honest as opposed to peer feedback (Vorobel \& Kim, 2017) and worst of all, some students thought that some of the peer comments might be wrong $(\mathrm{Ge}, 2019)$. It was perceived that some students did not provide helpful feedback and some others did not evaluate seriously (Chien, Hwang \& Jong, 2019). A few studies (Li \& Li, 2017; Shang, 2019) also found students' lack of confidence with their peers' ability to revise grammar. Some students, however, perceived that peers merely focused on grammatical/ typographical errors (Yang, 2015). Furthermore, students' perception of low-quality peer feedback and its resulting low credibility was also used to explain why they did not ask for clarification from their peers as anticipated ( $\mathrm{Wu}$, Petit \& Chen, 2015). Similarly, students' negative perception on the lack of quality of peer feedback was also reported in Gaynor's (2019) study, therefore reviewing/giving feedback was considered a more useful facet of the peer review process rather than receiving peer feedback.

\section{Lack of Active Response to Peer Feedback}

Students were found making no corresponding changes on $51 \%$ of peer comments (Walker, 2015). Extensive revisions were only noted in a small number of students and those who received informative peer response did not revise their work meaningfully (Magnifico, Woodard \& McCarthey, 2019). Similarly, it was found that $48 \%$ of feedback instances were not revised in a subsequent draft (Leijen, 2017). Moreover, it was found that only about $50 \%$ of correct peer comments were integrated even when students were supported with question prompts (Jurkowski, 2018). Also, it was found that some learners were unwilling to accept the extra information provided by their peers (Ge, 2019). Students' unwillingness to follow the peer's suggestion was again addressed by the students in Vorobel and Kim's (2017) study.

Possible reasons were suggested to explain the aforementioned issues. For instance, students' disagreement with peer comments and unwillingness to recognize the shortcomings of their work (Walker, 2015), students' lack of motivation during the revision process and their lack of confidence with the comments provided by their peers (Jurkowski, 2018), confusion/ misunderstanding caused by unclear feedback as well as the lack of knowledge of the issues highlighted (Al Qunayeer, 2019) were some of the reasons discussed. Students' limited English proficiency (Ge, 2019) may also demotivate them to use the information offered by their peers. On the other hand, ease of uptake was put forward to explain students' tendency to take up surface-level feedback more frequently than other types of feedback (Dressler, Chu, Crossman, \& Hilman, 2019), hinting the possibility that 
INTERNATIONAL JOURNAL OF ACADEMIC RESEARCH IN BUSINESS AND SOCIAL SCIENCES Vol. 10, No. 9, 2020, E-ISSN: 2222-6990 @ 2020 HRMARS

students might refrain themselves from making major changes to their initial work after receiving the peer feedback.

\section{Technical Issues Related to The Tools Used}

Students have also reported some difficulties related to the use of technological tools during peer review. Among which, limitations of Turnitin tool to let students clarify the doubts on a particular point and confusion caused when switching the tools ( $\mathrm{Li} \& \mathrm{Li}, 2017$ ), compatibility issues of SVVR application and its different volume sizes on different mobile devices (Chien, Hwang \& Jong, 2019), poor video/sound quality and slow loading in voice blog (Liu, 2016), limited commenting features of Twitter (Montero-Fleta, Pérez-Sabater \& Pérez-Sabater, 2015) were some of the issues highlighted. Besides, unfamiliarity with the tool, the issue of distraction and information overload were also reported in Luo's (2016) study. Students described the situation as 'chaotic' and they have difficulties to keep up with what was being discussed in Twitter-mediated peer feedback session.

\section{Others}

Some students highlighted that their peers did not show proper etiquette when communicating during peer feedback activity. Students reported that their peers did not use 'respectful word' when giving their comments (Li \& Li, 2017). This is echoed in another study when the word 'disrespectful' was used by a student in describing the peer feedback received (Luo, 2016). As suggested by Li and Li (2017), it is thus necessary to provide some guidance for students on how to draw on their pragmatic knowledge, use polite expressions and emoticons to tone down the negativity when providing feedback. Task-related issues such as having to produce a long learning film (Chien, Hwang \& Jong, 2019) and extra workload and time management (Grant, 2016; Liu, 2016) as well as the need to communicate face-to-face with peers (Grant, 2016) were also highlighted by students. Besides, some students reported that they preferred face-to-face ( $f 2 f)$ feedback more than online peer feedback due to issues related to delayed feedback. Also, the more personal nature of the $\mathrm{f} 2 \mathrm{f}$ interaction allows for more effective communication compared to online feedback session, which is viewed as lacking of non-verbal cues (Pritchard \& Morrow, 2017).

\section{Conclusion}

In sum, research on technology-supported peer feedback has centered on a few strands, focusing on different peer feedback types/ characteristics, student perceptions on their peer feedback experience and the impacts of peer feedback on student learning performance. Students' integration of peer feedback, which is a crtically underexplored facet, can be given more focus by future researchers. Furthermore, more studies should be conducted in speaking context in view of the relative paucity of such studies in the literature.

Though some arguments exist regarding the rich visual and auditory cues, i.e body language and tone of voice in a conventional face-to-face peer feedback session, as well as the concern of delayed response in an online environment (Pritchard \& Morrow, 2017), literature has shown that technology-supported peer feedback can offer a lot more potential advantages, particularly in providing opportunities for students to get high-quality feedback for their learning, promoting students' deep self-reflection as well as the affordances that lead to learners' convenience and ease. 
INTERNATIONAL JOURNAL OF ACADEMIC RESEARCH IN BUSINESS AND SOCIAL SCIENCES Vol. 10, No. 9, 2020, E-ISSN: 2222-6990 @ 2020 HRMARS

Given the potentially intimidating nature of face-to-face peer feedback, educators can consider the use of effective digital tools to help enhance the efficacy of peer feedback.

Though technology-supported peer feedback has been empirically proven to offer numerous merits, there is accumulating evidence that students' lack of confidence to provide feedback and their lack of trust in their peers' ability as assessors might affect the overall efficacy of peer feedback. Other vexing challenges are concerned with students' inability to provide constructive peer feedback and their lack of active response to peer feedback. As it was found that a lot of students have expressed their concerns on the aforementioned issues, proper guidance from teachers is thus called for to create a more non-threatening and supportive environment which is deemed necessary to enhance the efficacy of peer feedback in a technology-supported learning environment.

\section{Corresponding Author}

Catherine Nguoi Chui Lam, Faculty of Education, Universiti Teknologi Malaysia, 81310 Skudai, Malaysia, Email: catherinenguoi@yahoo.com

\section{References}

Akiyama, Y. (2017). Learner beliefs and corrective feedback in telecollaboration: A longitudinal investigation. System. https://doi.org/10.1016/j.system.2016.12.007

Al Qunayeer, H. S. (2019). Supporting postgraduates in research proposals through peer feedback in a Malaysian university. Journal of Further and Higher Education.

https://doi.org/10.1080/0309877X.2019.1627299

Braun, V., \& Clarke, V. (2006). Using thematic analysis in psychology. Qualitative research in psychology, 3(2), 77-101.

Chang, C. Y. H. (2015). Teacher modeling on EFL reviewers' audience-aware feedback and affectivity in L2 peer review. Assessing Writing. https://doi.org/10.1016/j.asw.2015.04.001

Cheng, K. H., Liang, J. C., \& Tsai, C. C. (2015). Examining the role of feedback messages in undergraduate students' writing performance during an online peer assessment activity. Internet and Higher Education. https://doi.org/10.1016/j.iheduc.2015.02.001

Chien S.-Y., Hwang G.-J. \& Jong, M. S-Y. (2019). Effects of peer assessment within the context of spherical video-based virtual reality on EFL students' English-Speaking performance and learning perceptions, Computers \& Education. doi: https://doi.org/10.1016/ j.compedu.2019.103751.

Cho, K., \& MacArthur, C. (2010). Student revision with peer and expert reviewing. Learning and Instruction, 20(4), 328-338. https://doi.org/10.1016/j.learninstruc.

Chwo, G. S. M. (2015). Empowering EIL learning with a Web 2.0 resource: An initial finding from the cross campus Storybird feedback study. Computers \& Education, 84, 1-7. doi:10.1016/j.compedu.2015.01.004

Clifford, J. (1981). Composing in stages: Effects of feedback on revision. Research in the Teaching of English, 15,37-53.

Dressler, R., Chu, M. W., Crossman, K., \& Hilman, B. (2019). Quantity and quality of uptake: Examining surface and meaning-level feedback provided by peers and an instructor in a graduate research course. Assessing Writing. https://doi.org/10.1016/j.asw.2018.11.001. 
INTERNATIONAL JOURNAL OF ACADEMIC RESEARCH IN BUSINESS AND SOCIAL SCIENCES Vol. 10, No. 9, 2020, E-ISSN: 2222-6990 @ 2020 HRMARS

Gaynor, J. W. (2019). Peer review in the classroom: student perceptions, peer feedback quality and the role of assessment, Assessment \& Evaluation in Higher Education, DOI: $10.1080 / 02602938.2019 .1697424$

Ge, Z.-G. (2019). Exploring the effect of video feedback from unknown peers on e-learners' EnglishChinese translation performance. Computer Assisted Language Learning, 1-21. doi:10.1080/09588221.2019.1677721

Gielen, M., \& De Wever, B. (2015). Scripting the role of assessor and assessee in peer assessment in a wiki environment: Impact on peer feedback quality and product improvement. Computers and Education. https://doi.org/10.1016/j.compedu.2015.07.012

Grant, S. (2016). Peer review process completion rates and subsequent student perceptions within completely online versus blended modes of study. System. https://doi.org/10.1016/j.system.2016.06.010

Hung, S. T. A. (2016). Enhancing feedback provision through multimodal video technology. Computers and Education. https://doi.org/10.1016/j.compedu.2016.03.009

Jurkowski, S. (2018). Do question prompts support students in working with peer feedback? International Journal of Educational Research. https://doi.org/10.1016/j.ijer.2018.07.003

Keele, S. (2007). Guidelines for performing systematic literature reviews in software engineering (Vol. 5). Technical report, Ver. 2.3 EBSE Technical Report. EBSE.

King, A. (2002). Structuring peer interaction to promote high-level cognitive processing. Theory into Practice, 41(1), 33-39.

Latifi, S., Noroozi, O., Hatami, J., \& Biemans, H. J. A. (2019). How does online peer feedback improve argumentative essay writing and learning? Innovations in Education and Teaching International, 1-12. doi:10.1080/14703297.2019.1687005

Leijen, D. A. J. (2017). A Novel Approach to Examine the Impact of Web-based Peer Review on the Revisions of L2 Writers. Computers and Composition. https://doi.org/10.1016/j.compcom.2016.11.005

Li, M., \& Li, J. (2017). Online Peer Review Using Turnitin in First-Year Writing Classes. Computers and Composition, 46, 21-38. https://doi.org/10.1016/j.compcom.2017.09.001

Lin, G. Y. (2018). Anonymous versus identified peer assessment via a Facebook-based learning application: Effects on quality of peer feedback, perceived learning, perceived fairness, and attitude toward the system. Computers and Education. https://doi.org/10.1016/j.compedu.2017.08.010

Liu, M. H. (2016). Blending a class video blog to optimize student learning outcomes in higher education. Internet and Higher Education. https://doi.org/10.1016/j.iheduc.2016.03.001

Liu, N.-F., \& Carless, D. (2006). Peer feedback: the learning element of peer assessment. Teaching in Higher Education, 11(3), 279-290. doi:10.1080/13562510600680582

Luo, T. (2016). Enabling microblogging-based peer feedback in face-to-face classrooms. Innovations in Education and Teaching International. https://doi.org/10.1080/14703297.2014.995202

Magnifico, A. M., Woodard, R., \& McCarthey, S. (2019). Teachers as co-authors of student writing: How teachers' initiating texts influence response and revision in an online space. Computers and Composition. https://doi.org/10.1016/j.compcom.2019.01.005

Montero-Fleta, B., Pérez-Sabater, C., \& Pérez-Sabater, M. L. (2015). Microblogging and Blended Learning: Peer Response in Tertiary Education. Procedia - Social and Behavioral Sciences, 191, 1590-1595. doi:10.1016/j.sbspro.2015.04.384 
INTERNATIONAL JOURNAL OF ACADEMIC RESEARCH IN BUSINESS AND SOCIAL SCIENCES Vol. 10, No. 9, 2020, E-ISSN: 2222-6990 @ 2020 HRMARS

Noroozi, O., \& Hatami, J. (2019) The effects of online peer feedback and epistemic beliefs on students' argumentation-based learning, Innovations in Education and Teaching International, 56:5, 548557, DOI: 10.1080/14703297.2018.1431143

Pritchard, R. J., \& Morrow, D. (2017). Comparison of Online and Face-to-Face Peer Review of Writing. Computers and Composition. https://doi.org/10.1016/j.compcom.2017.09.006

Qing, M. (2019). Examining the role of inter-group peer online feedback on wiki writing in an EAP context. Computer Assisted Language Learning, 1-20. doi:10.1080/09588221.2018.1556703

Shang, H.-F. (2019). Exploring online peer feedback and automated corrective feedback on EFL writing performance. Interactive Learning Environments, 1-13. https://scihub.tw/10.1080/10494820.2019.1629601

Sheen, Y. (2008). Recasts, language anxiety, modified output, and L2 learning. Language Learning, 58, 835-874. doi:10.1111/j.1467-9922.2008.00480.x

Topping, K. J. (2010). Methodological quandaries in studying process and outcomes in peer assessment. Learning and Instruction, 20(4), 339-343. https://doi.org/10. 1016/j.learninstruc.2009.08.003.

Van den Bos, A. H., \& Tan, E. (2019). Effects of anonymity on online peer review in second-language writing. Computers \& Education. https://doi.org/10.1016/j.compedu.2019.103638

Vorobel, O., \& Kim, D. (2017). Adolescent ELLs' collaborative writing practices in face-to-face and online contexts: From perceptions to action. System. https://doi.org/10.1016/j.system.2017.01.008

Walker, M. (2015) The quality of written peer feedback on undergraduates' draft answers to an assignment, and the use made of the feedback, Assessment \& Evaluation in Higher Education, 40:2, 232-247, DOI: 10.1080/02602938.2014.898737

Wu, W-C. V., Petit, E., \& Chen, C-H. (2015). EFL writing revision with blind expert and peer review using a CMC open forum, Computer Assisted Language Learning, 28:1, 58-80, DOI: 10.1080/09588221.2014.937442

Wu, Z. (2019). Lower English proficiency means poorer feedback performance? A mixed-methods study. Assessing Writing. https://doi.org/10.1016/j.asw.2019.05.001

Xiao, Y., \& Watson, M. (2017). Guidance on Conducting a Systematic Literature Review. Journal of Planning Education and Research, 0739456X1772397. doi:10.1177/0739456x17723971

Yang, Y.-F. (2015). Transforming and constructing academic knowledge through online peer feedback in summary writing. Computer Assisted Language Learning, 29(4), 683-

702. doi:10.1080/09588221.2015.1016440

$\mathrm{Yu}, \mathrm{S}$. (2019). Learning from giving peer feedback on postgraduate theses: Voices from Master's students in the Macau EFL context. Assessing Writing. https://doi.org/10.1016/j.asw.2019.03.004

Zheng, L., Cui, P., Li, X., \& Huang, R. (2017). Synchronous discussion between assessors and assessees in web-based peer assessment: impact on writing performance, feedback quality, metacognitive awareness and self-efficacy. Assessment \& Evaluation in Higher Education, DOI: 10.1080/02602938.2017.1370533 